\title{
Investigation of selenium levels in patients with fibrocystic breast disease
}

\section{Servet KOCAÖZ1 ${ }^{1}$ Ömer PARLAK²}

\footnotetext{
${ }^{1}$ Department of General Surgery, Atatürk Training and Research Hospital, Bilkent, Ankara, Turkey

${ }^{2}$ Department of General Surgery, Faculty of Medicine, Ankara Yıldırım Beyazıt University, Bilkent, Ankara, Turkey.
}

\section{ABSTRACT}

The present study was conducted to compare serum selenium levels in patients with breast pain. Patients with fibrocystic disease (FCD) and other breast pathologies were divided into two groups. Biochemical analysis and some habits of patients admitted to the general surgery outpatient clinic with breast pain were reviewed retrospectively. The serum selenium levels were found to be lower in patients with FCD than in those with other breast pathologies $(P<0.00001)$. At the same time, tea and cigarette consumption was higher in patients with FCD having breast pain $(P=0.026$ and $P=$ 0.034 , respectively). The serum selenium level was lower in patients with FCD who had breast pain than in patients with other benign breast pathologies. Tea and cigarette consumption was higher in these patients than in other patients. Further studies should monitor serum selenium levels indicating whether selenium supplementation is effective in patients with $F C D$.

Key words: Breast pain, fibrocystic breast disease, selenium

\section{INTRODUCTION}

Breast pain is seen in 41\%-79\% of women. It may lead to breast cancer in women and adversely affect daily life activity (1-3). Mastalgia can be categorized into four types: cyclic breast pain, noncyclic breast pain, chest wall pain, and pain from outside the chest wall (2). A strong relationship exists between breast pain and psychiatric disorders (anxiety and depression) and alcohol use and trauma history (3). In addition, stress, caffeine, smoking, lactation frequency, and breast benign disorders are associated with mastalgia (4). Cancer-related breast pain is noncyclic, unilateral, and well localized and is seen in $1.2 \%-3.2 \%$ of patients $(5,6)$. It is recommended to reduce weight and salt intake while managing mastalgia and pain (7). Iodine and selenium use was reported to reduce nodularity and the need for pain medication to relieve breast pain (8). The aim of this study was to compare the serum selenium levels of patients with pure fibrocystic changes in patients with breast pain and those with other breast pathologies.

\section{MATERIALS AND METHODS}

Between June 1, 2018, and November 1, 2018, the files of patients who presented to the general surgery outpatient clinic with complaints of breast pain were reviewed retrospectively. Serum selenium levels were studied, and ultrasonography (USG), mammography, biochemical tests (cholesterol, triglycerides), and prolactin levels were recorded from the hospital information system, which was routinely used in the follow-up of patients with breast pain. Patients who underwent all the radiological and biochemical tests were included in the study. They were randomly assorted into two groups ( $n=30$ in each group). Thirty patients diagnosed with pure fibrocystic disease (FCD) in Group 1 and 30 patients diagnosed with other than FCD in Group 2 were compared. No informed consent was required because this was a retrospective study and no

Ankara Atatürk Eğitim ve Araştırma Hastanesi, Genel Cerrahi Bölümü, Üniversiteler Mah. Bilkent cad., No:1, 06800 Çankaya, Ankara, Turkey. 


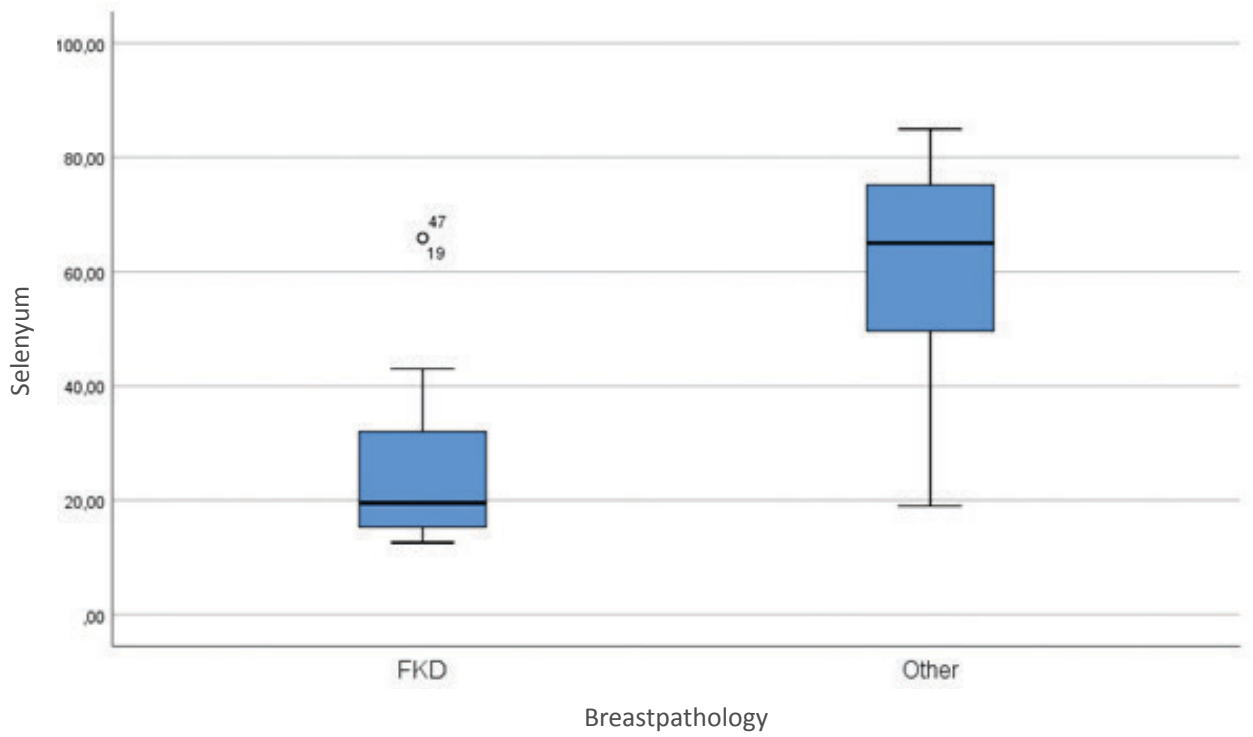

FIGURE 1: Serum selenium levels in FCD and other breast benign diseases.

identification data were used for the patients. Data were analyzed using the SPSS program (Version 25.0; SPSS Inc., IL, USA). The nonparametric Mann-Whitney $U$ test was used to analyze the data of the two groups that did not show a normal distribution (no normal distribution due to the Shapiro-Wilk test result being $<0.05)$. Nominal data were analyzed by the continuity correction test.

\section{RESULTS}

A total of 60 patients with breast pain were included in the study. The USGS of patients revealed the presence of pure FCD in Group 1 and FCD and/or other diseases in Group 2. The mean age of the patients was $42.2 \pm 9.97$ years (min: 21; med: 42.5; max: 63). When the selenium levels of the patients were compared, the mean selenium level in Group 1 was $24.99 \pm 14.15$, and the mean selenium level in Group 2 was $59.58 \pm 19.60$ (Figure 1). The selenium level was significantly lower in Group 1 than in Group 2
$(P<0.00001)$ (Table 1). Patients in Group 1 reported that they consumed significantly more tea than the patients in Group $2(P=$ 0.026). The serum selenium levels were found to be significantly lower in patients consuming tea very frequently $(P<0.00001)$. Smoking was significantly higher in Group 1 than in Group $2(P=$ 0.034) (Table 2). The serum cholesterol, triglyceride, and prolactin levels were not significantly different between the groups $(P=$ $0.160, P=0.141$, and $P=0.311$, respectively).

\section{DISCUSSION}

In this study, blood tests and some habits of patients with FCD having breast pain and other breast pathologies were compared. It provided information that can be used in treating breast pain and cysts in patients with FCD. A parallel relationship exists between breast pain and the size, number, and nodularity of cysts in FCD (8). Therefore, the pain is reduced with the shrinkage of the cysts in the breast. lodine use was reported to be effective in patients

\section{TABLE 1: Serum selenium level of patients.}

\begin{tabular}{llllllll}
\hline Breastpathology & N & Mean & Median & $\begin{array}{l}\text { Std. } \\
\text { Deviation }\end{array}$ & U & P \\
\hline Selenyum & FKD & 30 & 24,9927 & 19,5000 & 14,15038 & $81,500<0.0001$ & \\
& Other & 30 & 59,5807 & 65,0000 & 19,60453 & \\
& & & & & &
\end{tabular}


TABLE 2: Comparison of FCD and other breast benign diseases with high tea consumption.

\begin{tabular}{|c|c|c|c|c|c|c|c|}
\hline & & & \multicolumn{3}{|c|}{ FKD } & \multirow{2}{*}{$\begin{array}{l}\text { Continuity } \\
\text { Correction }\end{array}$} & \multirow[b]{2}{*}{$P$} \\
\hline & & & FKD & Other & Total & & \\
\hline \multirow[t]{4}{*}{ Tea Consumption } & Low tea concumption & Count & 5 & 14 & 19 & 4.929 & 0.026 \\
\hline & & $\%$ within TC & $26,3 \%$ & $73,7 \%$ & $100,0 \%$ & & \\
\hline & Very tea concumption & Count & 28 & 13 & 41 & & \\
\hline & & $\%$ within TC & $68,3 \%$ & $31,7 \%$ & $100,0 \%$ & & \\
\hline \multirow[t]{4}{*}{ Smoking } & I don't smoke & Count & 7 & 16 & 23 & 4.512 & 0.034 \\
\hline & & $\%$ within smoking & $30,4 \%$ & $69,6 \%$ & $100,0 \%$ & & \\
\hline & I smoke & Count & 23 & 14 & 37 & & \\
\hline & & $\%$ within smoking & $62,2 \%$ & $37,8 \%$ & $100,0 \%$ & & \\
\hline \multirow[t]{2}{*}{ Total } & Count & 30 & 30 & 60 & & & \\
\hline & $\%$ & $50,0 \%$ & $50,0 \%$ & $100,0 \%$ & & & \\
\hline
\end{tabular}

with breast pain and tenderness (9). The addition of gammalinolenic acid and selenium to the diet of patients with iodine has been reported to reduce nodularity by reversing the effects of 17-beta-estradiol in the breast (10). In the present study, the serum selenium levels were found to be below the normal values in most patients with FCD. Selenium is a component of the glutathione peroxidase enzyme, which protects the cell from the negative effects of hydrogen peroxide and organic peroxides by means of its anti-oxidant properties (11). Selenium strengthens the immune system, increases the yawning ability of the heart and vessels, regulates thyroid functions, and increases fertility in men and women. Selenium, above all, acts as an anti-cancer agent (12). It has a protective effect by binding to toxic metals such as cadmium, arsenic, mercury, and lead. Reduction of selenium intake has been reported to increase the risk of breast, lung, prostate, and colon cancers $(13,14)$. A serum selenium level above $64.4 \mu \mathrm{g} / / \mathrm{L}$ has positive effects on the treatment (15). However, care should be taken to avoid selenium toxicity when using selenium to prevent cancer. Taking more than $400 \mu \mathrm{g}$ of selenium daily has been reported to cause toxic effects. Among the toxic effects of selenium, loss of vision, muscular and tooth decay, bad taste and odor in the mouth, skin changes, hair loss, and nail breakage have been reported. Therefore, intake of $55-70 \mu \mathrm{g}$ of selenium supplement per day has been recommended (16). The results of this study indicated that the majority of patients with FCD had low selenium levels. Supplementation with routine selenium in addition to foods may cause toxic effects while treating patients with FCD. Therefore, it is recommended that selenium supplementation and serum selenium levels should be monitored in patients with low serum selenium levels. In the present study, the serum selenium levels were found to be low in patients who consumed tea very often. Low serum selenium level, depending on the substances in the tea due to the deterioration of selenium absorption shows that develops (17). No previous study investigated the use of selenium replacement therapy in patients with FCD who had low serum selenium levels. Therefore, further studies are needed to examine the selenium level in a larger FCD population and explore the use of selenium replacement therapy in patients with low selenium levels.

\section{CONCLUSIONS}

Serum selenium levels were found to be low in most patients with FCD. Tea and cigarette consumption was higher in these patients than in other patients. It is more appropriate to look at the serum selenium level before selenium supplementation to patients' diet. However, further studies should monitor serum selenium levels indicating whether selenium supplementation is effective in patients with FCD.

\section{REFERENCES}

1. Brown N, Burnett E, Scurr J. Is Breast Pain Greater in Active Females Compared to the General Population in the UK? Breast J 2016 22(2):194-201.

2. Goyal A. Breast Pain. BMJ Clin Evid 2011 17;2011. pii: 0812. 
3. Johnson KM, Bradley KA, Bush K, Gardella C, Dobie DJ, Laya MB. Frequency of mastalgia among women veterans. Association with psychiatric conditions and unexplained pain syndromes. J Gen Intern Med 2006 21(3):S70-5.

4. Eren $T$, Aslan A, Ozemir IA, Baysal H, Sagiroglu J, Ekinci O et al. Factors Effecting Mastalgia. Breast Care (Basel) 2016 11(3):188-93.

5. Joyce DP, Alamiri J, Lowery AJ, Downey E, Ahmed A, McLaughlin R et al. Breast clinic referrals: can mastalgia be managed in primary care? Ir J Med Sci 2014 183(4):639-42.

6. Tumyan L, Hoyt AC, Bassett LW. Negative predictive value of sonography and mammography in patients with focal breast pain. Breast J 2005 11(5):333-7.

7. Koçoğlu D, Kurşun S, Akın B, Altuntug K. Mastalgia and associated factors: a cross-sectional study. Agri 2017 29(3):100-8.

8. Mansel RE, Das T, Baggs GE, Noss MJ, Jennings WP, Cohen J et al. A Randomized Controlled Multicenter Trial of an Investigational Liquid Nutritional Formula in Women with Cyclic Breast Pain Associated with Fibrocystic Breast Changes. J Womens Health (Larchmt) 2018 27(3):333-40.

9. Kessler $\mathrm{JH}$. The effect of supraphysiologic levels of iodine on patients with cyclic mastalgia. Breast J 2004 10(4):328-36.

10. Martin TA, Das T, Mansel RE, Jiang WG. Enhanced tight junction function in human breast cancer cells by antioxidant, selenium and polyunsaturated lipid. J Cell Biochem 2007 1;101(1):155-66.
11. Dumont E, Vanhaecke F, Cornelis R. Selenium speciation from food source to metabolites: a critical review. Anal Bioanal Chem 2006 385(7):1304-23.

12. Bodnar M, Szczyglowska M, Konieczka P, Namiesnik J. Methods of Selenium Supplementation: Bioavailability and Determination of Selenium Compounds. Crit Rev Food Sci Nutr. 2016;56(1):36-55.

13. Navarro-Alarcon $M$, Cabrera-Vique $C$. Selenium in food and the human body: a review. Sci Total Environ 2008 1;400(1-3):115-41.

14. Ekoue DN, Zaichick S, Valyi-Nagy K, Picklo M, Lacher C, Hoskins K, Warso MA, Bonini MG, Diamond AM. Selenium levels in human breast carcinoma tissue are associated with a common polymorphism in the gene for SELENOP (Selenoprotein P). J Trace Elem Med Biol 2017 39:227-233.

15. Lubinski J, Marciniak W, Muszynska M, Huzarski T, Gronwald J, Cybulski $C$ et al. Serum selenium levels predict survival after breast cancer. Breast Cancer Res Treat 2018 167(2):591-598.

16. Agarwal $P$, Sharma $S$, Agarwal US. Selenium toxicity: A rare diagnosis. Indian J Dermatol Venereol Leprol 2016 82(6):690-693.

17. Borawska MH, Witkowska AM, Hukałowicz K, Markiewicz R. Influence of dietary habits on serum selenium concentration. Ann Nutr Metab 2004;48(3):134-40. 